\title{
A Benefits Assessment Model of Information Systems for Small Organizations in Developing Countries
}

\author{
Amal Alshardan ${ }^{1,2}$, Robert Goodwin ${ }^{1} \&$ Giselle Rampersad $^{1}$ \\ ${ }^{1}$ School of Computer Science, Engineering and Mathematics, Flinders University, Adelaide, Australia \\ ${ }^{2}$ Faculty of Computer and Information Sciences, Princess Nourah University, Riyadh, Saudi Arabia \\ Correspondence: Amal Alshardan, School of Computer Science, Engineering and Mathematics, Flinders \\ University, Adelaide, Australia. E-mail: alsh0249@flinders.edu.au
}

Received: September 22, 2015

Accepted: November 3, 2015

Online Published: December 12, 2015

doi:10.5539/cis.v9n1p1

URL: http://dx.doi.org/10.5539/cis.v9n1p1

\begin{abstract}
The influence of information systems (IS) on small and medium-sized enterprises (SMEs) has enjoyed much attention by managers and policy makers. Despite the hype and eagerness to commit extensive levels of investment, very little research has focuses on assessing the benefits of IS for SMEs in developing countries. Existing literature has been skewed towards developed countries and large organizations. Consequently, the purpose of this paper is to develop a model for evaluating the benefits of IS for SMEs in Saudi Arabia as a case of a developing country. In order to achieve this, the study builds on and extends past IS-impact literature. Based on quantitative results of 365 responses from SMEs, the model comprises 44 measures across five dimensions: 'Individual impact', 'Organisational impact', 'System quality', 'Information quality' and 'Vendor quality'. Applying confirmatory factor analysis and structural equation modelling, the validated model contributes to theory development of IS impact within the context of SMEs in developing countries. Additionally, it provides critical insights to policy makers and managers on assessing the benefits of IS for SMEs in developing countries.
\end{abstract}

Keywords: IS Success, IS Impact, measurement models, benefits assessment, information systems evaluation, SMEs, developing countries

\section{Introduction}

Information systems (IS) have been heralded as key agents for social well-being and economic prosperity in developing countries (Patel, Sooknanan, Rampersad, \& Mundkur, 2012; Rampersad \& Troshani, 2013). They have been recognised as critical for innovation in such economies (Lin, 1998; Rampersad, Quester, \& Troshani, 2009; Rampersad, Troshani, \& Plewa, 2012; Snider, da Silveira, \& Balakrishnan, 2009). Additionally, small and medium sized enterprises (SMEs) have been identified for their important role in such innovation and wealth creation (Alshardan, Goodwin, \& Rampersad, 2013; Lin, 1998; Snider et al., 2009). Despite this vital contribution, SMEs face significant challenges, for instance limited funding, and unfeasibly high costs of systems development and implementation (Freel, 2000). Therefore, measuring and assessing the benefits of IS in SMEs will be valuable in contributing towards the success of these systems (Mirani \& Lederer, 1998).

Although many significant measurement techniques and frameworks are used to measure the benefits of IS (e.g. DeLone \& McLean, 1992; DeLone \& McLean, 2003; Gable, Sedera, \& Chan, 2008; Shang \& Seddon, 2002) these models are predominantly based on the context of large organisations. Studies have shown that SMEs are not smaller replicas of large firms as they are fundamentally different from large firms due to their special characteristics and requirements (Martin-Tapia, Aragon-Correa, \& Senise-Barrio, 2008). SMEs face a digital divide from their larger counterparts, evidenced by significant differences in IS-related activities such as e-commerce and e-procurement (Lefebvre \& Lefebvre, 1992; Levy \& Powell, 1998). Moreover, these differences are perpetuated by the lack of agreement on what actually comprises an SME (O'Reagan \& Ghobadian., 2004) as well as by the mythical concepts around SMEs (Gibb, 2000).

A digital divide exists not only between small and large organizations, but also between developed and developing countries. Developing countries have substantially different business environments compared to those of developed countries in terms of laws and regulations, governmental control, workforce characteristics, management style and customer income characteristics (Al-Mabrouk \& Soar, 2006; Alghamdi, Goodwin, \& 
Rampersad, 2011b; Fathian, Akhavan, \& Hoorali, 2008; Grazzi \& Vergara, 2012). Roztocki and Weistroffer (2011) highlight the high failure rate of IS implementation in developing countries and point out that IS applications in developed countries have a "different focus as mature infrastructure is already in place, and project success is often determined by very different criteria" (p. 164). In addition, Soja (2008) emphasises the difficulties in IS implementation in developing countries that pertain primarily to the human resource constraints and high costs.

Most of the research on IS success in SMEs or in large organisations has been conducted in the developed nations' context. There is a lack of research in the developing countries' context, in general, and, in particular, on IS success in SMEs in the Saudi Arabian context (Al-Gahtani, Hubona, \& Wang, 2007; AlGhamdi, Nguyen, Nguyen, \& Drew, 2012; Azyabi, Fisher, Tanner, \& Gao, 2014; Waverman, Coyle, \& Souter, 2011; Wei, Loong, Leong, \& Ooi, 2009). Saudi Arabia provides a suitable context for this study for a number of reasons. First, the ICT sector in Saudi Arabia has become the largest and fastest growing ICT marketplace in the Arab region with strong growth rates set to expand at a compound annual growth rate of $11.4 \%$ through 2015: this rapid growth is fuelled mostly by increased spending on hardware and IT services (AlGhamdi, 2012). Second, the Saudi government has made a significant commitment to growing the SME sector as exemplified by its Ninth Development Plan 2010-2014 plan for economic development focuses on smaller employers with firms encouraged through motivation and loans to increase their spending on research and development (R\&D) (Alenaizan, 2014). Furthermore, the focus on software spending has improved with over $75 \%$ of manufacturing, services and trading companies in Saudi Arabia considering new deployments or upgrades of ERP solutions (Business Monitor International, 2012). Therefore, given the importance of the SME sector to Saudi Arabia, it will greatly benefit from relevant studies to ensure the success of IS implementation in SMEs in developing countries (Consoli, 2012; Manochehri, Al-Esmail, \& Ashrafi, 2012).

\section{Literature Review}

\subsection{Information Systems Success}

Information Systems (IS) have become very important software applications with a significant influence on the business world, and thus have attracted high levels of investment (Petter, DeLone, \& McLean, 2008). Despite the anticipated benefits, few studies actually examine the success of such systems to ensure that benefits do materialise. However, measuring such success is challenging due to the lack of consensus on contributing factors (Irani, 2008). Firstly, the impact of IS is indirect and is influenced by many factors, such as human, organisational and environmental ones. The mixture of the technical and social aspects of an IS make such measurements complex and confusing (Petter et al., 2008). Secondly, IS and work practices are very entangled thus making it difficult to identify their discrete influence on success (Agourram, 2009). The third point is related to the methodological perspectives that are used to measure IS success in which identifying dependent variables is difficult (Agourram, 2009).

Another important cause for the difficulty in evaluating results is the difference pertaining to the meaning of information systems (IS). The term 'information systems (IS)' is a broad name that can refer to many types of IS used in organisations, such as decision support systems (DSSs), computer-mediated communications, e-commerce and knowledge management systems (Petter et al., 2008). Depending on the type of system, the ways of measuring the success of IS may vary.

Moreover, the use of IS in SMEs have been underexplored. Within SMEs, the systems chosen are different to those originally used by many studies of large organizations, such as those by Gable et al. (2008) and Shang and Seddon (2002). Consequently, this may affect the measures and dimensions of the model, as many existing IS measures are related to the features of IS for large organisations.

During the past few decades, many efforts have been made to identify the factors that contribute to IS success. A number of models have been proposed for measuring IS (DeLone \& McLean, 1992, 2003; Gable et al., 2008; Shang \& Seddon, 2002).

To the best of the researchers' knowledge, no comprehensive benefits measurement model exists for IS success for SMEs of a developing country. The existing studies on IS success in SMEs and its evaluation remain under-developed. Many prior studies on IS in SMEs have focused on adoption (e.g. Fink, 1998; Juell-Skielse, 2006) and implementation success (e.g. Koh, Gunasekaran, \& Cooper, 2009; Loh \& Koh, 2004; Mabert, Soni, \& Venkataramanan, 2003a, 2003b; Snider et al., 2009; Sun, Yazdani, \& Overend, 2005), while few studies have attempted to measure benefits. Therefore, developing a benefits measurement framework is essential for evaluating IS in SMEs in the context of developing countries in order to justify the value and contribution of IS in relation to productivity. The following subsection firstly reviews some important IS success models, and then 
discusses various issues regarding these models in the context of SMEs and developing countries.

\subsubsection{DeLone and McLean $(1992,2003)$ Models}

The DeLone and McLean $(1992,2003)$ models are probably the most cited models in the IS community. DeLone and McLean (1992) carried out a review of the research published during the period 1981-1987. Based on this review, they created an IS success taxonomy. Thus, a full set of 119 success measures was summarised into six categories or components of IS success: 'System quality', 'Information quality', 'Use', 'User satisfaction', 'Individual impact' and 'Organisational impact'. Figure 1 shows this original IS success model (DeLone \& McLean, 1992).

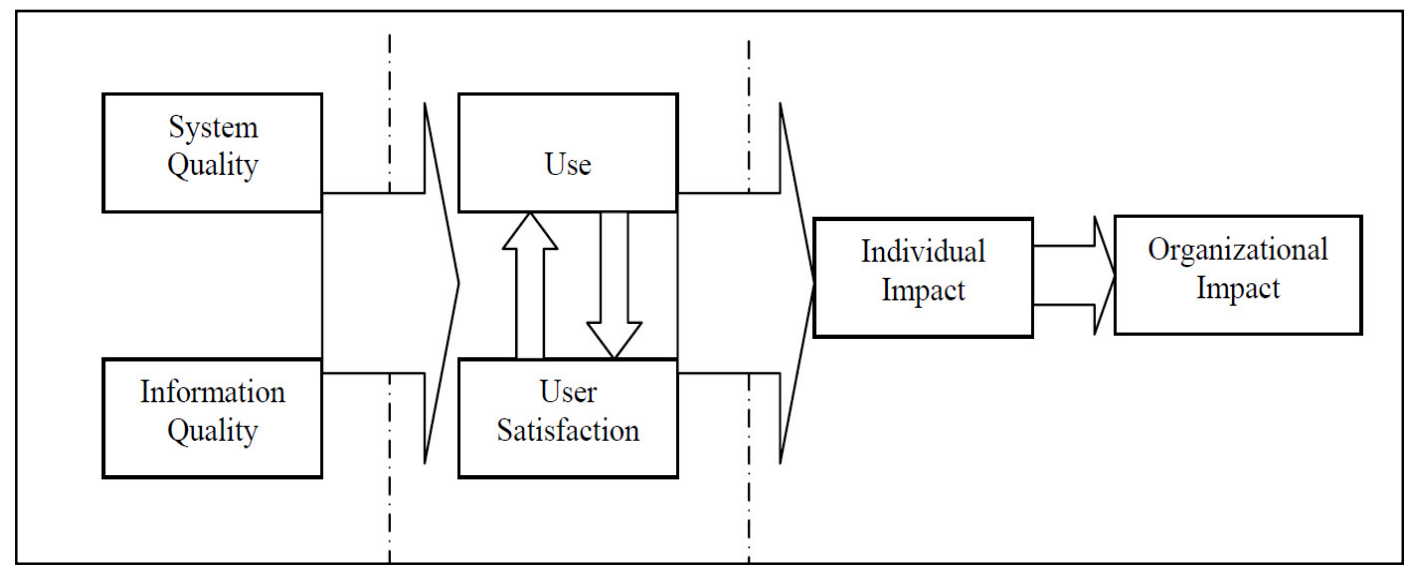

Figure 1. Delone and Mclean (1992) Is Success Model

The 1992 model was successfully tested in many empirical studies (Agourram, 2009). In addition, many researchers have suggested modifications or improvements to their model. Based on these improvements and other alternative frameworks for measuring IS effectiveness, DeLone and McLean conducted an in-depth analysis and reflection, and then updated their model and proposed the new DeLone and McLean (2003) IS success model (see Figure 2).

The D\&M model opened the gate for many researchers: they either empirically tested the model in different contexts or criticised and enhanced some of its aspects.

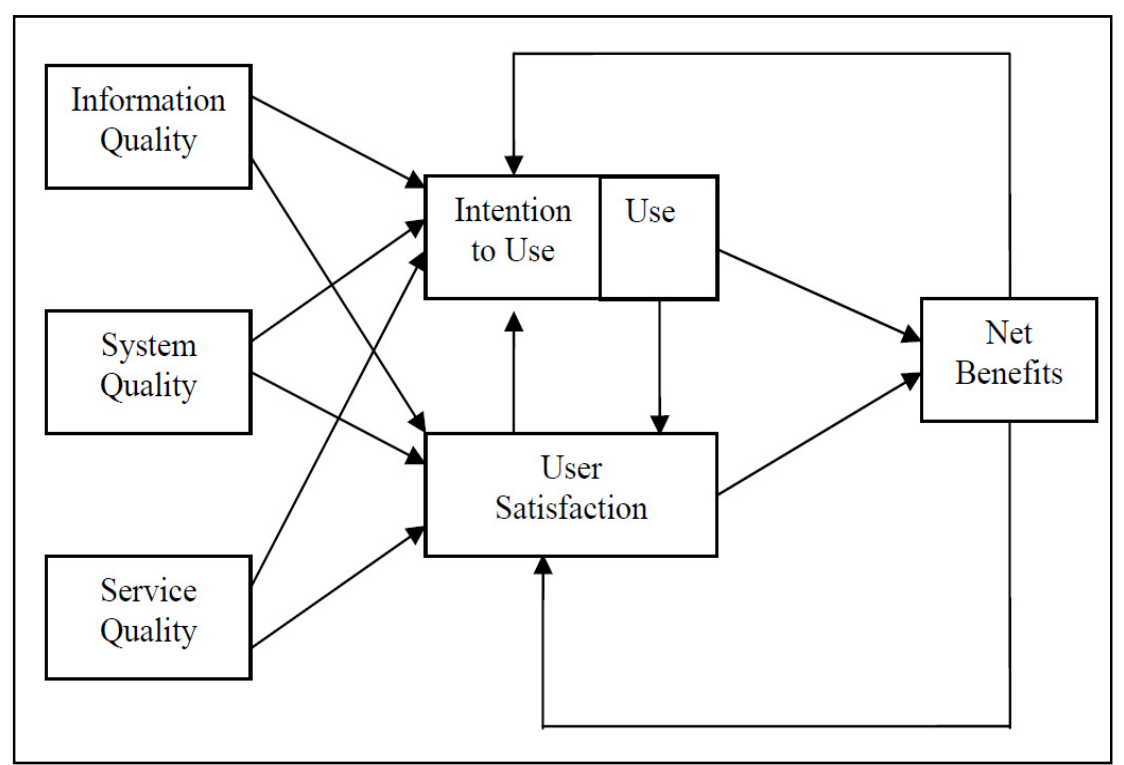

Figure 2. DeLone and McLean's (2003) IS success model 


\subsubsection{The IS-Impact Model}

Based on DeLone and McLean's (1992) IS success model and tests of other researchers' work (Myers, Kappelman, \& Prybutok, 1998; Shang \& Seddon, 2002), Gable et al. (2008) developed a more advanced IS-Impact model. To obtain and validate this model, the authors employed three surveys (an identification survey, a specification survey and a confirmatory survey) with data collected from 600 respondents. The identification survey aimed to specify the salient success dimensions and measures; the specification survey was then used to identify the a priori model; while the purpose of the confirmatory survey was to validate the a priori model and instrument (Gable et al., 2008). Using a multi-method research design, Gable et al. (2008) extended the research cycle proposed by MacKenzie and House (1978) and McGrath (1964) to develop and validate a measurement model. Their research entailed two main phases: an exploratory phase to develop the hypothesised model and a confirmatory phase to test the model against the collected data.

The authors defined the IS impact of an information system (IS) as "a measure at a point in time of the stream of net benefits from the IS, to date and anticipated, as perceived by all key user groups" (Gable et al., 2008, p. 10). Thus, the IS-Impact model is represented as two halves: the 'impact' half measures the net benefits to date and the 'quality' half measures the possible future impacts (Gable et al., 2008). Three important issues addressed in their paper reconceptualise IS success, namely, the completeness, mutual exclusivity and necessity of the dimensions and measures.

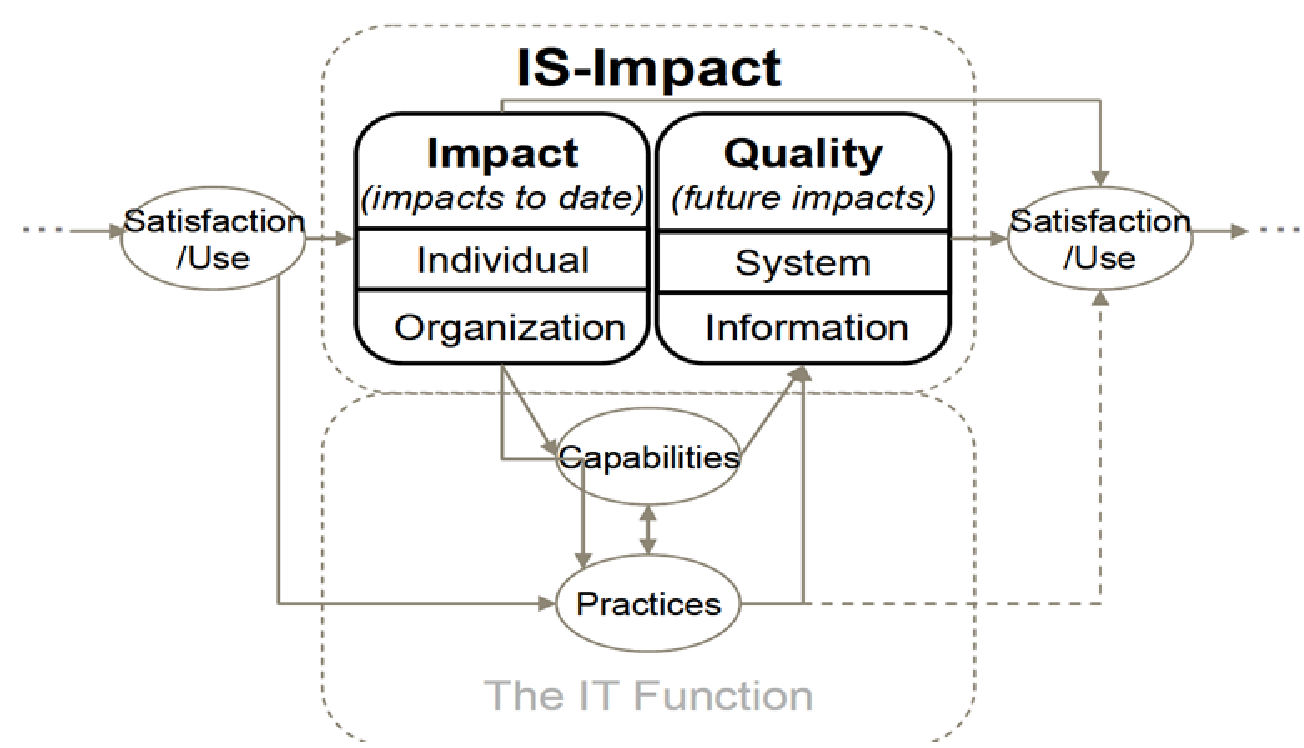

Figure 3. The IS-Impact measurement model (adopted from (Gable et al., 2008))

The IS-Impact model consists of four constructs: 'Individual impact', 'Organisational impact', 'System quality' and 'Information quality'. These represent four distinct but related dimensions of the multidimensional phenomenon, namely, enterprise systems (ES) success (otherwise termed IS success). Furthermore, it has always been debated whether the constructs of 'Use' and 'Satisfaction' are dimensions of IS success. Through a comprehensive exploratory study, Gable et al. (2008) drew the following conclusion: both 'Use' and 'Satisfaction' are antecedents or consequences of IS impact rather than being two dimensions. When evaluating an ES, measures of these dimensions represent variables that are highly comparable across time, stakeholders, various types of system and different contexts. The impact dimensions represent the benefits that have been achieved from the system. The quality dimensions reflect future potential; hence, these four dimensions reflect a complete view of the measure of ES success (Gable et al., 2008) (see Figure 3).

The IS-Impact model is differentiated from DeLone and McLean's IS success model in the following ways: (1) it illustrates a measurement model while the D\&M model depicts a causal/process model of success; (2) the addition of new measures reflects a more holistic view of the context of ERP systems and organisational characteristics; (3) it includes additional measures to probe the 'Organisational impact' construct; (3) it eliminates and consolidates measures; and (4) it revisits the relevance of the 'Use' and 'Satisfaction' constructs (Gable et al., 2008). Moreover, the original 37 measures were reduced to 27 measures in this IS-Impact model, in 
the interests of parsimony. The 37 measures of IS impact are shown in Figure 4.

The current study focuses on the underlying theories which can explain the new phenomenon of the evaluation of IS by SMEs in developing countries. The study therefore assists in the development of a benefits measurement framework for IS in SMEs. Unlike other studies that have been based on the D\&M model, the current study is based on the IS-Impact model. Justification for any update to the model is thus provided in accordance with the rationale and reasoning derived from existing theories and models. The D\&M model, as stated at the outset, has been tested and used in many contexts and has proven its validity for use in other contexts (Urbach, Smolnik, \& Riempp, 2009). The IS-Impact model is chosen due to its ability to measure the up-to-date impact of the system undergoing evaluation, as well as its ability to forecast the potential impact of a future system by evaluating the quality of information and the system itself. This model is concise and parsimonious which makes it practical and easy to use. Moreover, the model measures the level of impact across multiple staff perspectives in an organisation. The advantages of the IS-Impact model form a sound underlying base that can be validated in the context of SMEs.

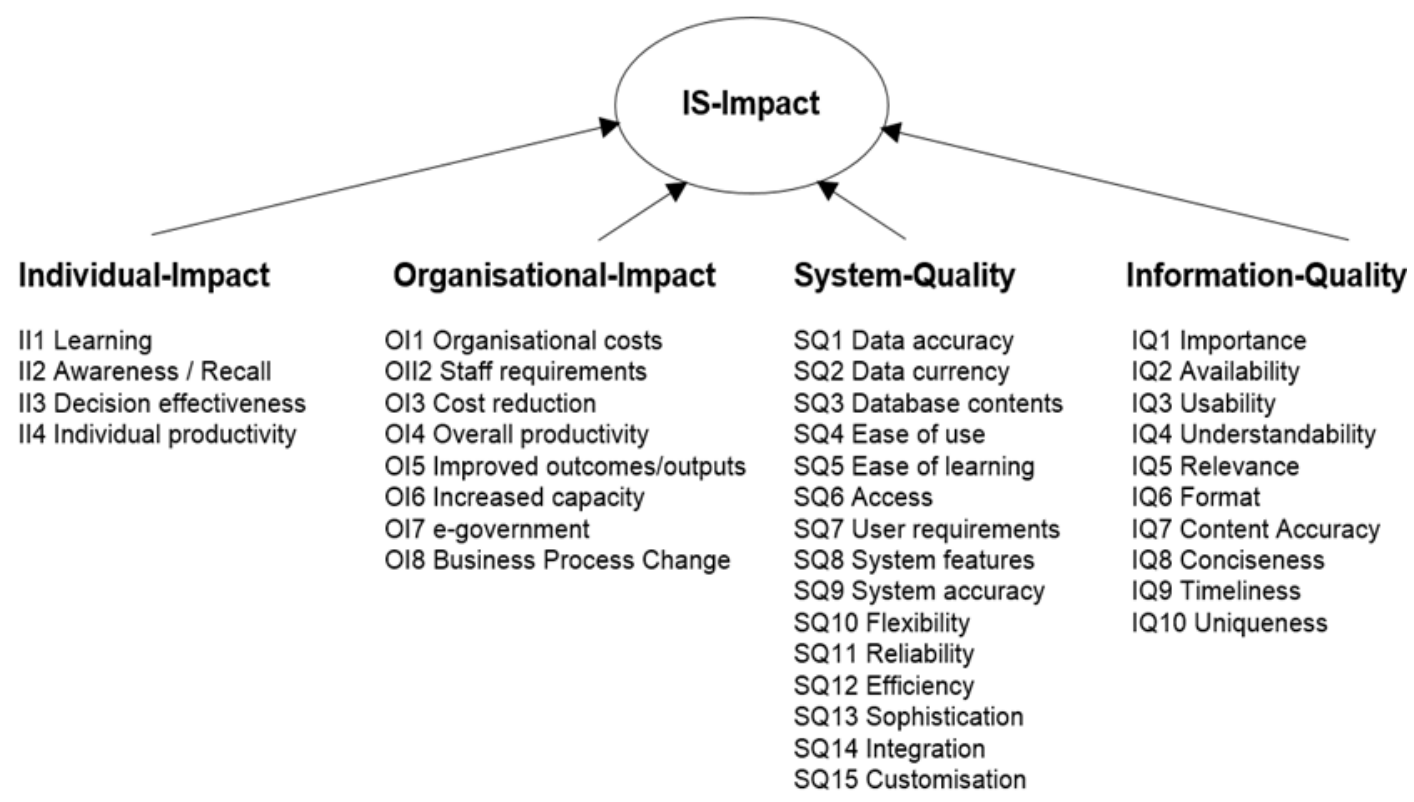

Figure 4. IS-Impact model's 37 measures (extracted from Gable et al. [2008])

\subsection{Small and Medium-Sized Enterprises (SMEs)}

SMEs have a strong influence on the economic growth of all countries. They play an important role in employment and innovation (Lin, 1998; Snider et al., 2009). They differ fundamentally from large organizations in several ways, such as having limited resources, the inadequacy of employees' skills, uncertainty towards IS and a lack of vision for their prospective competitive advantages (Salmeron \& Bueno, 2006).

Traditionally, IS investment has been dominated by large organisations. This phenomenon is no longer the case: SMEs are increasingly implementing IS and, in addition, many software package vendors are now considering SMEs as a focal market. Despite this trend, a feature in most SMEs is less management support for IS (Levy \& Powell, 2000; Snider et al., 2009) with managers in SMEs tending to give insufficient attention to IS (Cragg \& Zinatelli, 1995 ; Yap, Soh, \& Raman, 1992). SMEs are also characterised by less experience with IS in comparison with large organisations: they have only become computerised relatively recently and have little experience and training in IS management (Blili \& Raymond, 1993; DeLone, 1981).

With regard to the type of IS used in SMEs, IS within SMEs are not at a very advanced stage and are subordinate to the accounting function (Blili \& Raymond, 1993). Moreover, most SMEs expect their IT to have a longer life than is the expectation of larger firms. What this means is that many SMEs are locked into systems developed using advanced tools that are unsupported or incompatible with current industry standards (Levy \& Powell, 2000). The SME characteristics that might affect several aspects of IS and hence have the probability of changing the measures of IS success models are described in the following paragraphs. Despite the obvious 
effects of specific IT/IS SME characteristics, it is evident that the general characteristics of SMEs also affect many aspects of IT and information systems (IS). Many academics have remarked on some of these aspects either empirically or conceptually. For example, the centralised SME structure affects creativity, innovation, response times and the decision-making orientation of problem-solving actions (Levy \& Powell, 2000; McCartan-Quinn \& Carson, 2003), all of which are aspects related to IT/IS adoption and implementation.

The majority of SMEs do not have adequate financial resources and lack access to commercial lending or the ability to obtain credit. In addition, SMEs are faced with frequent raw material shortages, fluctuations in raw material price, and inadequate inventory management and stock control (Deros, Yusof, \& Salleh, 2006). Consequently, in relation to IS, SMEs do not have an adequate budget for staff training and consultancy support nor for adequate hardware and software which can stifle improvement efforts and lead to difficulty in the implementation of IS projects. Therefore, SMEs may be more severely impacted by unsuccessful implementation, with these weaknesses leading to project delays or even abandonment (Snider et al., 2009). In terms of human resources, SMEs are always faced with the lack of expertise and lack of skilled employees because they are not able to offer workers better wages and working conditions (Deros et al., 2006). This, in turn, affects all phases of IS from planning and operation through to maintenance and updates. It also increases the need for external support and expertise. Snider et al. (2009) found that internal training teams often suffer from lack of time and skills to prepare and deliver effective training sessions. Moreover, the majority of SME entrepreneurs have low levels of formal education and limited training in new management principles and practices (Deros et al., 2006). General resistance to change or to the adoption of new ideas is another characteristic of SMEs (Seibert, 2004). As indicated by many researchers such as Deros et al. (2006) and Kartiwi and MacGregor (2007), the majority of SMEs rely on out-of-date technology. The reason is that some SMEs do not trust new technology, while others are unable to afford it which, in many cases, leads to inefficiency, misinformation and inadequate in-house expertise (Deros et al., 2006)

In summary, SMEs have special characteristics that differentiate them from large organisations. These characteristics play an important role in IS adoption, use and management. Having an understanding of the issues and characteristics of SMEs is crucial before making any attempt to measure IS success.

\subsection{Developing Countries and the Use of Information Systems (IS)}

Academic researchers have differentiated between developed and developing countries as two different contexts due to government regulations, economic laws and other social factors that could affect research findings.

This research has been undertaken in the developing countries' context. The use of IS in developing countries continues to be challenging due to several factors (Alghamdi, Goodwin, \& Rampersad, 2011a; Alghamdi et al., 2011b). Information system (IS) products are not often tailored to the unique needs of developing countries as they were initially designed for the markets of developed countries (Berisha-Namani, 2009). Furthermore, limited financial resources (Berisha-Namani, 2009) and inadequate expertise and human resources in SMEs in developing countries (Berisha-Namani, 2009) and the lack of robust regulatory frameworks for IS in developing countries pose major problems. In non-English speaking contexts, the language barrier is also of consideration for developing countries as some citizens may not necessarily know other languages beyond the local language whereas IS products may, for example, be dominated by English-language content (Grazzi \& Vergara, 2012).

With the growing importance of IS in SMEs in developing countries, researchers have begun to investigate the adoption and use of IS in contexts such as Malaysia (Alam \& Noor, 2009), Nigeria (Irefin, Abdul-Azeez, \& Tijani, 2012) and the Kingdom of Saudi Arabia (KSA) (Skoko, 2012; Skoko \& Ceric, 2010). Generally, the focus of existing studies is on pre-implementation considerations surrounding IS in SMEs in developing countries rather than on post-implementation issues (e.g. Apulu \& Latham, 2010; Ashrafi \& Murtaza, 2008; Berisha-Namani, 2009; Manochehri, Al-Esmail, \& Ashrafi, 2012; Modimogale \& Kroeze, 2011). Only a limited number of studies have attempted to measure the post-implementation benefits of IS in SMEs in developing countries (Ndiege, Wayi, \& Herselman, 2012). For instance, Kale, Banwait and Laroiya (2010) surveyed 130 SMEs in India to find out whether and how Indian SMEs are benefiting from IS implementation for enterprise resource planning (ERP). Their study revealed that most SMEs implemented a new IS to integrate with the existing IS and found IS implementation was mainly beneficial in reducing inventory, improving customer services and improving communications. In addition, the study found that top management support, and user involvement and participation are the major contributors to IS success (Kale et al., 2010). In Jordan, Hawari and Heeks (2010) developed a "design-reality gap" model and applied it to a case study of IS failure in a Jordanian manufacturing firm. Analysing the situation both before and during IS implementation through a combination of interviews, observations and document analyses, Hawari and Heeks (2010) found sizeable gaps between the 
assumptions and requirements built into the IS design and the actual realities of the client organisation. Their model was derived from different IS success measurement models which comprised seven dimensions summarised by the ITPOSMO acronym (information, technology, processes, objectives and values, staffing and skills, management system and structure and other resources) (Hawari \& Heeks, 2010). Ndiege et al. (2012) focused on assessing the quality of IS used by SMEs in Kenya. They found that the low usage of IS within SMEs was attributed to the low level of IS skills of both SME management and IS users, and to poorly designed IS that did not adequately address the needs of SMEs. They also evaluated the quality of IS in SMEs in developing countries by applying the D\&M model and found the quality to be barely sufficient (Ndiege et al., 2012). Similarly, in Malaysia, Wei, Loong, Leong and Ooi (2009) presented a re-specification of the D\&M model. They proposed a conceptual model that resulted from a comprehensive review of the IS success literature. Their results provided an expanded understanding of the factors that measure IS success and suggested ways to improve IS usage (Wei et al., 2009). A recent study by Ghobakhloo and Tang (2015) developed an integrated IS success model based on the D\&M model and the technology-organisation-environment (TOE) framework of the firm. Their model was tested using data based on 316 respondent Iranian and Malaysian manufacturing SMEs. Their model shows that the determinants of IS success for SMEs incorporate both organisational and environmental determinants in addition to the technological factors identified in the D\&M model (Ghobakhloo \& Tang, 2015).

Despite the value of previous studies in their examination of IS benefits in specific countries, a more comprehensive model is needed. The current study has proposed a conceptual model that stems from an extensive review of SME characteristics and IS success models. The study has also employed the highly relevant IS-Impact model as the theoretical base, extending beyond the typical D\&M model.

\section{The Research Model}

The research model proposed in this study is the result of a synthesis process included the IS-Impact model with characteristics and studies of SMEs in developing countries. This combination was performed in order to respond to two main issues around IS success modelling, namely, the theoretical basis and validity in the SME context with these providing both rationality and generality for the measurement model (Ahlan, 2014).

Figure 5 demonstrate this model. Details of the dimensions of IS success in SMEs are shown in Table 2 and the set of measures for each dimension are shown in Table 3.

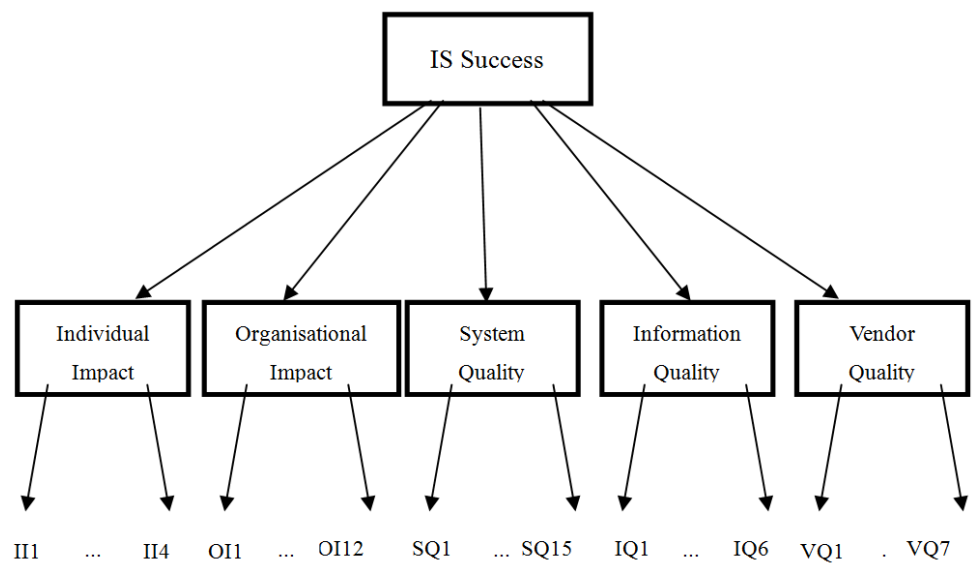

Figure 2. The a priori model of IS success measurement in SMEs in developing countries

Table 2. Dimensions of IS success in SMEs in developing countries

\begin{tabular}{lcl}
\hline \multicolumn{1}{c}{ Dimension } & $\#$ & \\
& Items & \multicolumn{1}{c}{ Definition } \\
\hline Individual impact & 4 & $\begin{array}{l}\text { The benefits received by the IS recipient due to IS applications (DeLone \& } \\
\text { McLean, 1992) }\end{array}$ \\
$\begin{array}{l}\text { Organisational } \\
\text { impact }\end{array}$ & 12 & $\begin{array}{l}\text { The firm-level benefits received by an organisation due to IS applications } \\
\text { (Gorla, Somers, \& Wong, 2010). }\end{array}$ \\
\hline
\end{tabular}




\begin{tabular}{lcl}
\hline System quality & 15 & The desirable characteristics of the IS applications (Petter et al., 2008). \\
Information quality & 6 & $\begin{array}{l}\text { The desirable characteristics of the system's outputs (Petter et al., 2008). } \\
\text { Vendor quality }\end{array}$ \\
$\begin{array}{l}\text { Total } \\
\text { The quality of the support that system users receive from the IS vendor (Petter et } \\
\text { al., 2008). }\end{array}$ \\
\hline
\end{tabular}

Table 3. Set of measures for each dimension

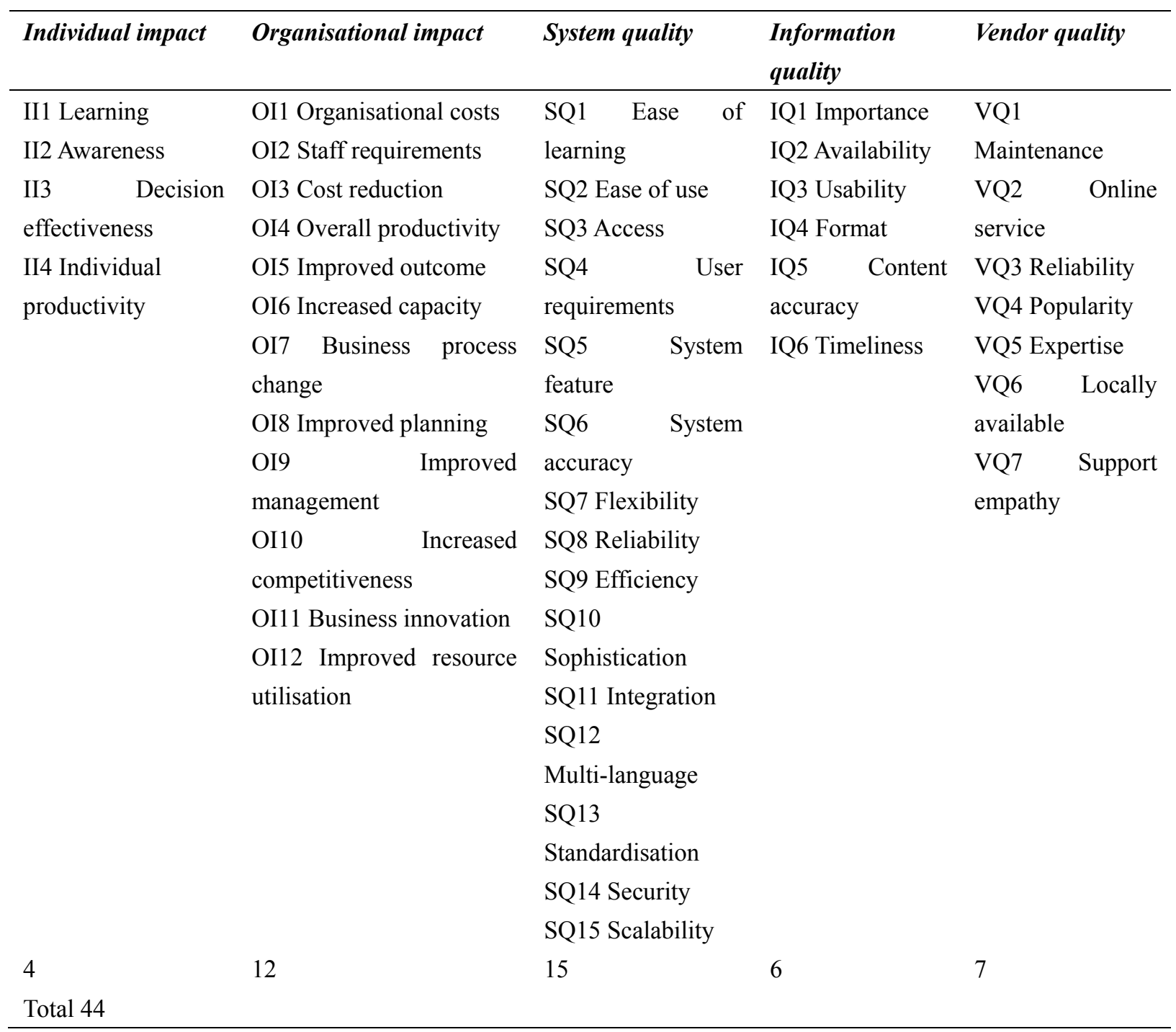

\section{Model Validation}

The proposed model was validated using a survey method to collect data. A total of 431 responses were received from SMEs in Saudi Arabia: 365 were complete and valid for analysis. Respondents were classified according to demographic questions which sought information about respondents and their organisation. Table 4 shows frequencies of demographic variables.

Structural equation modelling (SEM) and second-order confirmatory factor analysis (CFA) were conducted sequentially to evaluate and test statistically significant relationships between the model constructs. Based on these results, the model was further refined by removing non-significant links and then reassessed to produce the final model. The final model was assessed for goodness of fit, reliability and validity as discussed in the next subsections.

Confirmatory factor analysis (CFA) is a special form of factor analysis used to test whether the data fit a 
hypothesised measurement model (Schreiber, Nora, Stage, Barlow, \& King, 2006). Confirmatory factor analysis (CFA) techniques were performed in this study using SPSS AMOS, Version 22 software.

The main reason for choosing CFA was that it is more theoretically driven unlike exploratory factor analysis (EFA) which has been identified as a data-driven technique (Barendse, Oort, \& Timmerman, 2015). CFA allows researchers to base their hypothesised models on the required theory in order to defend the relationships between constructs and also in terms of justifying the number of factors required for each construct.

The assessment process for the model using CFA comprised scale refinement for each construct, then assessing the structural model fit. Finally, assessment of reliability and validity was undertaken.

Assessing the model at both construct and structural levels involved multiple iterations of applying goodness-of-fit indices to test statistically significant relationships between the model constructs and variables (independent and dependent variables). Based on the results of the fit indices, the model was refined by removing non-significant links and then reassessed to produce the final model. Another modification to the model that helped to achieve an acceptable fit was using correlation between errors of the variable as suggested by (Lance, 2011). Furthermore, under certain conditions of unidimensionality, parcelling can be considered for a better fit (Little, Cunningham, Shahar, \& Widaman, 2002; Yang, Nay, \& Hoyle, 2009).

First, in line with the suggestions of many scholars (e.g. Rampersad, Quester, \& Troshani, 2010; Schumacker \& Lomax, 2004), the model was tested at the construct level using CFA, prior to combining the constructs structurally (the structural model). This was important for diagnosing and reducing problems that could amalgamate at later stages (Rampersad, 2008). Therefore, a test was performed for each construct in isolation and some modification was undertaken to achieve the required fit. The structural model fit was then assessed as a second stage with the third stage being the assessment of reliability and validity. Slight modifications were performed in order to achieve a perfect fit for the structural model, with validity and reliability addressed.

The following subsections detail the procedure for the three stages: assessment of constructs' fit; assessment of structural model fit; and assessment of reliability and validity.

Table 4. Frequencies of demographic variables

\begin{tabular}{llll}
\hline Class & Group & Frequency & Percentage \\
\hline Gender & Male & 244 & $66.8 \%$ \\
Age & Female & 112 & $30.7 \%$ \\
& Less than 20 & 17 & $4.7 \%$ \\
& Between 20 and 29 & 121 & $33.2 \%$ \\
& Between 30 and 39 & 158 & $43.3 \%$ \\
& Between 40 and 49 & 55 & $15.1 \%$ \\
Position & 50 or over & 8 & $2.2 \%$ \\
& Owner & 175 & $47.9 \%$ \\
& Management staff & 94 & $25.8 \%$ \\
Qualifications & Operational staff & 31 & $8.5 \%$ \\
& IT staff & 51 & $14.0 \%$ \\
& Less than high school & 27 & $7.4 \%$ \\
Organisation's main sector & High school & 94 & $25.8 \%$ \\
& Bachelor degree & 194 & $53.2 \%$ \\
& Postgraduate degree & 45 & $12.3 \%$ \\
& Manufacturing & 77 & $21.1 \%$ \\
& Trade & 145 & $39.7 \%$ \\
& Services & 137 & $37.5 \%$ \\
Nize of the organisation & Small & 173 & $47.4 \%$ \\
& Medium-sized & 178 & $48.8 \%$ \\
& Large & 12 & $3.3 \%$ \\
& $<10$ & 134 & $36.7 \%$ \\
& 10 to $<50$ & 126 & $34.5 \%$ \\
& 50 to $<100$ & 69 & $18.9 \%$ \\
& $>$ or $=100$ & 32 & $8.8 \%$ \\
& Total in each group & 365 & $100.0 \%$ \\
\hline
\end{tabular}




\subsection{Assessment of Constructs' Fit}

As a first step in using CFA as the analysis technique, each construct was assessed by applying various measures of model fit, seeking a good fit that could be justified according to previous theories and studies. Checking for model fit at the construct level prior to combining the constructs structurally was important as a scale refinement step to help identify and tackle model fit problems that could otherwise emerge later (Rampersad, 2008).

The sequential evaluation and tests indicated the final representation of each construct with the factor loading of the items on their expected latent constructs being greater than 0.70 and significant at $p<0.001$. All constructs showed a perfect to acceptable fit as shown in Table 5 .

Table 5. Model fit at the construct level

\begin{tabular}{llllllllll}
\hline Construct & Chi-sq & $d f$ & $\begin{array}{l}\text { p-value } \\
>0.05\end{array}$ & $\begin{array}{l}\text { GFI } \\
>0.90\end{array}$ & AGFI & $\begin{array}{l}\text { CFI } \\
>0.95\end{array}$ & $\begin{array}{l}\text { TLI } \\
>0.95\end{array}$ & $\begin{array}{l}\text { RMSEA } \\
<0.08\end{array}$ & $\begin{array}{l}\text { SRMR } \\
<0.05\end{array}$ \\
\hline Individual impact & 3.34 & 1 & 0.68 & 0.99 & 0.95 & 0.99 & 0.99 & 0.80 & 0.0059 \\
Organisational impact & 65.6 & 19 & 0 & 0.95 & 0.915 & 0.98 & 0.97 & 0.82 & 0.0246 \\
System quality & 87.42 & 26 & 0 & 0.95 & 0.912 & 0.98 & 0.97 & 0.061 & 0.0259 \\
Information quality & 14.32 & 8 & 0.074 & 0.99 & 0.97 & 0.99 & 0.99 & 0.47 & 0.0123 \\
Vendor quality & 7.515 & 5 & 0.185 & 0.99 & 0.98 & 0.99 & 0.99 & 0.037 & 0.0126 \\
\hline
\end{tabular}

\subsection{Assessment of Structural Model Fit}

Structural equation modelling (SEM) was sequentially conducted to evaluate and test the statistically significant relationships between the model constructs.

Some adjustments to the scales were required, such as the removal of items and parcelling. In the initial phase, five constructs with 44 items in a second-order CFA (the original model) were used to test the structural model. Based on the results, the model was further refined sequentially by removing non-significant links and then reassessed for reliability and validity. Another suggested refinement based on the result was also applied by constructing an upper-level construct, with this process called 'parcelling' (Little et al., 2002). Figure 6 shows this refinement where the impact constructs are combined into another latent variable called 'Impacts' which refers to both 'Individual impact' and 'Organisational impact'. Similarly, 'System quality', 'Information quality' and 'Vendor quality' are combined into the latent construct 'Quality'. This refinement fulfils Gable et al.'s (2008) IS impact definition and the IS-Impact conceptual model. This result was also supported by Rabaa'i (2012) study in which the original IS-Impact model was combined with the IS support model in a structural model that related to satisfaction. This refinement shows good fit, convergent validity and discriminant validity. Therefore, this model was chosen as the final model for the study. Table 6 shows the goodness-of-fit indices for the final model.

Table 6. Goodness-of-fit indices for the final model

\begin{tabular}{lllllllllll}
\hline Model & Chi-sq. & $d f$ & $\begin{array}{l}p \text {-value } \\
>0.05\end{array}$ & $X^{2}$ & $\begin{array}{l}\text { GFI } \\
>0.90\end{array}$ & AGFI & $\begin{array}{l}\text { CFI } \\
>0.95\end{array}$ & $\begin{array}{l}\text { TLI } \\
>0.95\end{array}$ & $\begin{array}{l}\text { RMSEA } \\
<0.08\end{array}$ & $\begin{array}{l}\text { SRMR } \\
<0.05\end{array}$ \\
\hline Final model & 485.8 & 262 & 0 & 1.9 & 0.90 & 0.88 & 0.97 & 0.97 & 0.048 & 0.036 \\
\hline
\end{tabular}

\subsection{Assessment of Reliability and Validity}

All scales were evaluated for reliability and validity. Owing to the importance of this validation, Straub, Boudreau, and Gefen (2004) suggested the use of more than one method to test validity and reliability arguing that "establishing construct validity should be a mandatory research practice" (p. 398). In this study, each construct was assessed against the following aspects: indicator reliability, internal consistency reliability, convergent validity and discriminant validity.

\subsubsection{Reliability}

Reliability is a crucial analysis to be performed on the scale refers to its consistency, given the same conditions (Pallant, 2013). In this study, the analysis of scale reliability was performed through an assessment of indicator reliability and internal consistency reliability (Bannigan \& Watson, 2009; Hinkin, 1995).

Internal consistency refers to the homogeneity of the items in the measure or the extent to which item responses correlate with the total test score. Internal consistency can be measured using different methods, for instance, 
split halves, Kuder-Richardson approaches (KR-21) and Cronbach's alpha (Fraenkel \& Wallen, 2009). The current study evaluated internal consistency using Cronbach's alpha value as it is the most frequently employed method for determining internal consistency (Cooper \& Schindler, 2006; Fraenkel \& Wallen, 2009; Gliem \& Gliem, 2003; Kimberlin \& Winterstein, 2008). The values of Cronbach's alpha range between zero (0) and one (1), with a value between 0.8 and 0.95 referring to very good reliability. (Gliem \& Gliem, 2003). Five independent scales were used in the survey questionnaire that constructed the proposed model, namely, 'Individual impact', 'Organisational impact', 'System quality', 'Information quality' and 'Vendor quality'. Table 7 summarises the results of Cronbach's alpha for all constructs, showing that the internal reliability for all the variables/dimensions was very good as their values are greater than 0.92 . Based on these scores, the internal consistency (or the homogeneity) of the measures was confirmed.

Indicator reliability refers to how much of the indicator's variance is explained by the corresponding factor that it measures (Bannigan \& Watson, 2009; Gliem \& Gliem, 2003; Kimberlin \& Winterstein, 2008). Some researchers have proposed that at least $50 \%$ of the indicator's variance should be explained by the latent variable that it measures (Gliem \& Gliem, 2003; Kimberlin \& Winterstein, 2008). However, others have suggested that construct reliability scores should exceed 0.7 (Bagozzi \& Yi, 2011; Gefen, Straub, \& Boudreau, 2000; Gliem \& Gliem, 2003). In the current study, the indicator reliability for each construct is shown on Table 7. All constructs demonstrated indicator reliability. 


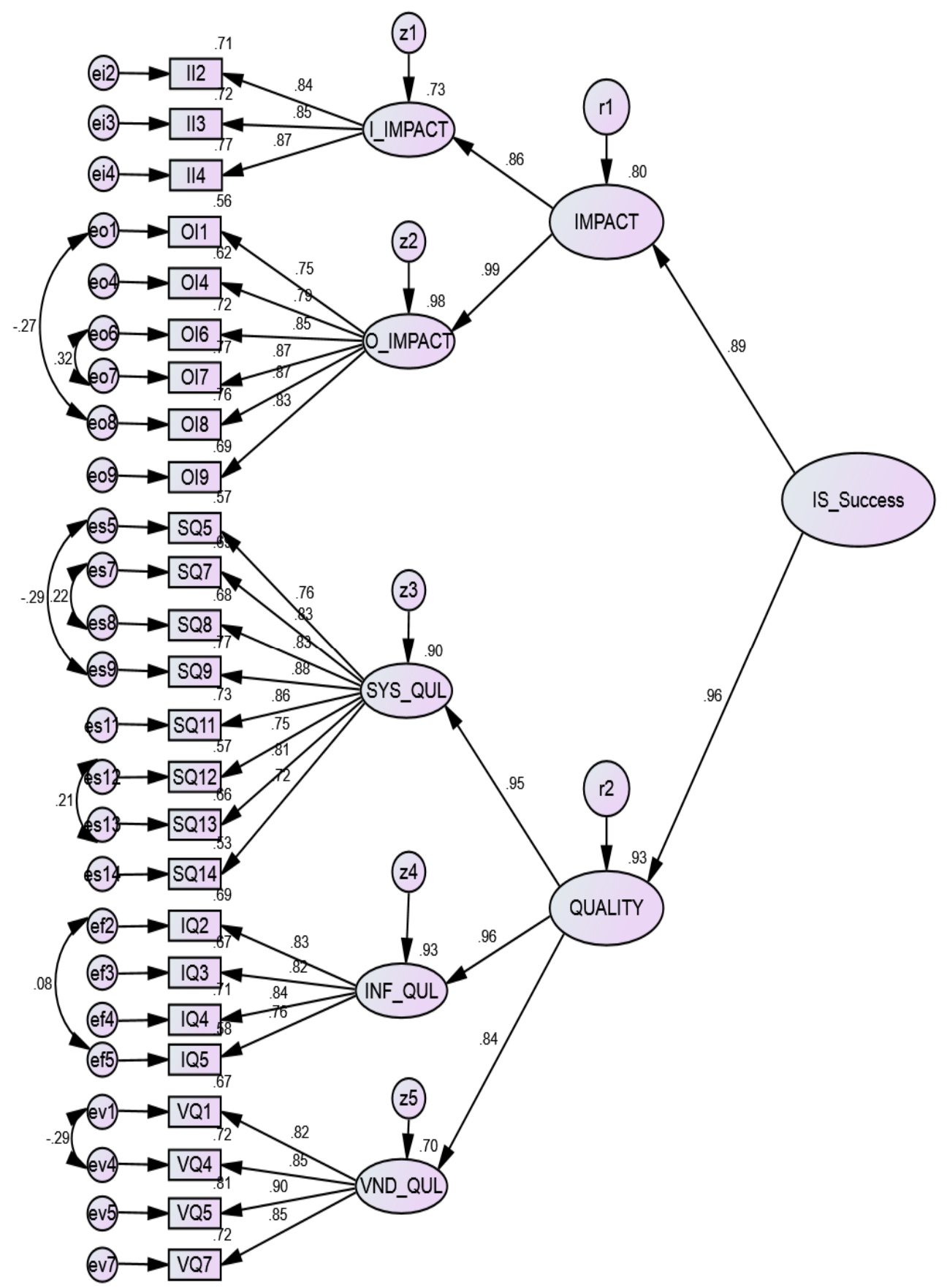

Figure 6. The Final Validated model

Table 7. Reliability results for the final model

\begin{tabular}{lll}
\hline Construct & Cronbach's alpha & Indicator reliability* \\
\hline Individual impact & .925 & .716 \\
Organisational impact & .962 & .888 \\
System quality & .963 & .955 \\
Information quality & .928 & .949 \\
Vendor quality & .938 & .846 \\
\hline
\end{tabular}

*Indicator reliability = standardised regression weights = factor loadings 


\subsubsection{Validity}

Validity is the measure of the accuracy of an instrument used in a study: checking the validity is essential to ensure that the scale measures what it is intended to measure (Bannigan \& Watson, 2009; Hair, Black, Babin, Anderson, \& Tatham, 2006; Said, Badru, \& Shahid, 2011). This study has examined for convergent validity and discriminant validity which are usually termed 'construct validity' (Doll, Xia, \& Torkzadeh, 1994; Hurley et al., 1997).

Convergent validity is intended to assess the extent to which the indicators are related to the same construct (Davis, 1989). To demonstrate convergent validity, the magnitude of the direct structural relationship between the indicator and latent construct should be statistically different from zero (0); that is, the final items should be loaded highly on one construct (Anderson \& Gerbing, 1988) with a factor loading of 0.50 or greater (Hair et al., 2006). In addition to the standardised factor loadings, convergent validity in this study was examined by observing the value of composite or construct reliability (CR) and variance extracted (VE) for each construct (Fornell \& Larcker, 1981; Hair et al., 2006). According to Hair et al. (2006), composite or construct reliability (CR) values should be greater than 0.6 while variance extracted (VE) should be above 0.5 . Values outside these limits indicate that the items have a convergent validity issue and might not consistently measure the hypothesised model. The values of composite or construct reliability (CR) and AVE were computed as shown in Table 8 . The results confirmed the convergent validity of all constructs.

Discriminant validity determines that each measurement item does not correlate too highly with all other constructs except the one to which it is theoretically associated. Average variance extracted (AVE) is also used to substantiate the evidence of the discriminant validity of the latent construct (Fornell \& Larcker, 1981). The values of average variance extracted (AVE) between the constructs are compared to their squared multiple correlations (SMCs) (Hair et al., 2006). Thus, the AVE for a latent construct should be greater than the variance shared between the construct and other latent constructs in the model (Fornell \& Larcker, 1981; Hair et al., 2006). As shown in Table 9, all constructs in this study exhibited discriminant validity as their values for variance extracted (AVE) were all above 0.500 , thus exceeding the square of the highest shared variance between factors.

Table 8 . Validity results for the final model

\begin{tabular}{lllll}
\hline Construct & $\boldsymbol{C R}^{*}$ & $\boldsymbol{A V \boldsymbol { E } ^ { * }}$ & $\boldsymbol{M S \boldsymbol { V } ^ { * }}$ & $\boldsymbol{A S \boldsymbol { V } ^ { * }}$ \\
\hline Impact & 0.92 & 0.85 & 0.74 & 0.74 \\
Quality & 0.94 & 0.84 & 0.74 & 0.74 \\
\hline
\end{tabular}

${ }^{*} \mathrm{CR}=$ composite reliability; $\mathrm{AVE}=$ average variance extracted; $\mathrm{MSV}=$ maximum shared variance; and $\mathrm{ASV}=$ average shared variance.

Table 9. Assessment criteria for reliability and validity

\begin{tabular}{|c|c|c|c|}
\hline Assessment & $\begin{array}{l}\text { Criterion/ } \\
\text { Criteria }\end{array}$ & Accepted values or conditions & Related references \\
\hline $\begin{array}{l}\text { Indicator } \\
\text { reliability }\end{array}$ & Factor loading & $\begin{array}{l}\text { Factor loading should be }>0.60 \text {, or } \\
\text { ideally }>0.7 \text {, and statistically significant }\end{array}$ & $\begin{array}{l}\text { (Bagozzi \& Yi, 2011; } \\
\text { Gefen et al., 2000; Gliem } \\
\text { \& Gliem, 2003) }\end{array}$ \\
\hline $\begin{array}{l}\text { Internal } \\
\text { consistency } \\
\text { reliability }\end{array}$ & Cronbach's alpha & $\begin{array}{l}\text { For confirmatory research, value should } \\
\text { be }>0.8\end{array}$ & (Cronbach, 1951) \\
\hline \multirow[t]{2}{*}{$\begin{array}{l}\text { Convergent } \\
\text { validity }\end{array}$} & AVE & $\mathrm{AVE}>0.5$ & $\begin{array}{l}\text { (Fornell \& Larcker, 1981; } \\
\text { Hair et al., 2006) }\end{array}$ \\
\hline & Factor loading & Factor loading $\geq 0.50$ & $\begin{array}{l}\text { (Anderson \& Gerbing, } \\
\text { 1988; Hair et al., 2006) }\end{array}$ \\
\hline $\begin{array}{l}\text { Discriminant } \\
\text { validity }\end{array}$ & $\begin{array}{lr}\text { Fornell } & \text { and } \\
\text { Larcker's } & (1981) \\
\text { criterion } & \text { using } \\
\text { AVE } & \\
\end{array}$ & $\begin{array}{l}\text { Latent variable's AVE is greater than the } \\
\text { squared bivariate correlations between it } \\
\text { and other latent variables in the model }\end{array}$ & $\begin{array}{l}\text { (Fornell \& Larcker, 1981; } \\
\text { Hair et al., 2006) }\end{array}$ \\
\hline
\end{tabular}




\section{Conclusion}

This research proposed and evaluated a measurement model for SMEs in developing countries. The focus of the study is on Saudi Arabian SMEs. The findings of the model test have suggested that a significant relationship exists between the five dimensions and IS success, and that the developed scale for each factor was rational and supported by other studies. The contexts of SMEs and developing countries were found to affect many parts of the model.

This research contributes to both theory and practice. In terms of the contribution to academic theory, this research contributes to the body of knowledge around research on SMEs and the measurement of IS success. First and foremost, this research has introduced a theoretical model to measure the success of IS in SMEs in Saudi Arabia as a case in the developing countries' context. The focus of previous studies in measuring IS success were on developed countries whereas the developing country context is still under-researched (Alghamdi et al., 2011a; Alshardan et al., 2013; Grazzi \& Vergara, 2012; Roztocki \& Weistroffer, 2011; Vrgovic, Glassman, Walton, \& Vidicki, 2012).

In addition, this study has contributed to the theory by extending and further empirically testing the IS-Impact model developed by Gable et al. (2008) in a different setting than was used in previous studies. In developing the current study's model, it was argued that the previously implemented IS-Impact model was deficient in the 'Vendor (service) quality' dimension in the context of SMEs in developing countries, whereas the other four dimensions of the IS-Impact model were confirmed. The study thus incorporated the 'Vendor quality' dimension into the existing dimensions of the IS-Impact model which was found to be relevant in this discourse on IS system success. Moreover, the operationalised set of measures offers comprehensive items that can be used as a basis for research in other contexts in order to establish standardised scales.

Last but not least, this research has contributed to the literature in the Saudi Arabian SME context on which there was a paucity of research, in general, and, in particular, on the IS aspects. Although this research was conducted in the Saudi context, the findings could be applicable to similar business contexts in developing countries, particularly in countries of the Gulf Cooperation Council (GCC) (i.e. Kuwait, United Arab Emirates [UAE], Qatar, Bahrain and Oman).

In addition, the study offers important implications for policy makers and managers in developing countries. At the government level, for example, this research could help policy makers in determining interventions to optimise the monitoring of IS initiatives to ensure the effective allocation of scarce public funding. Consequently, development goals pertaining to redressing digital divide concerns in relation to IS success could be achieved. SMEs could also find this research valuable in offering insights into the development of processes to manage IS implementation to ensure that organisations could reap the anticipated benefits. Useful guidelines could be provided for the senior management of SMEs that suggest the particular factors which SME management should use in assessing the success of IS in their companies. In addition, by assessing the benefits of IS, this research could help IS vendors to identify key growth opportunities for achieving desirable benefits and a way by which to evaluate IS applications, thus being able to address any shortfall in promised benefits. Hence, this study could provide valuable insights for both government and businesses in developing strategies to realise the anticipated benefits of IS for SMEs in developing countries. Indeed, this study is instrumental as a necessary first step in equipping SMEs in developing countries with a useful framework by which to assess the benefits of information systems (IS).

\section{Future Work}

The limitations of this research provide a natural guide to future research. As is typical, the investigation of more SMEs could result in more accurate findings. This could include SMEs in the Saudi Arabian context, or in the context of other developing countries.

Future research could examine the use of other types of IS such as customer relationship management (CRM), supply chain management (SCM) and the content management system (CMS). In addition, more advanced technical systems could be involved by using the implementation of cloud computing, such as software as a service (SaaS) that provides users with complete software applications on the internet (Tate, Sedera, McLean, \& Burton-Jones, 2014). Therefore, studies on major differences in the success factors of different IS projects in the organisation could form a key direction for future research.

In summary, this study has made an important contribution in paving the way for such future research by providing a more holistic framework for the measurement of IS benefits in the context of SMEs and developing countries. It is anticipated that the findings of this research, along with the areas identified for guiding future 
research, will motivate researchers to pursue this exciting research stream.

\section{References}

Agourram, H. (2009). Defining information system success in Germany. International Journal of Information Management, 29(2), 129-137. http://dx.doi.org/10.1016/j.ijinfomgt.2008.05.007

Ahlan, A. R. (2014). Implementation of Input-Process-Output Model for Measuring Information System Project Success. TELKOMNIKA Indonesian Journal of Electrical Engineering, 12(7). http://dx.doi.org/10.11591/telkomnika.v12i7.5699

Alam, S. S., \& Noor, M. K. M. (2009). ICT adoption in small and medium enterprises: an empirical evidence of service sectors in Malaysia. International Journal of Business and Management, 4(2), P112. http://dx.doi.org/10.5539/ijbm.v4n2p112

Al-Gahtani, S. S., Hubona, G. S., \& Wang, J. (2007). Information technology (IT) in Saudi Arabia: Culture and the acceptance and use of IT. Information \& Management, 44(8), 681-691. http://dx.doi.org/10.1016/j.im.2007.09.002

Alghamdi, I. A., Goodwin, R., \& Rampersad, G. (2011b). E-Government Readiness Assessment for Government Organizations in Developing Countries. Computer and Information Science, 4(3), 1913-1938. http://dx.doi.org/10.5539/cis.v4n3p3

Alghamdi, I., Goodwin, R., \& Rampersad, G. (2011a). A Suggested E-Government Framework for Assessing Organizational E-Readiness in Developing Countries Informatics Engineering and Information Science (pp. 479-498). http://dx.doi.org/10.1007/978-3-642-25453-6_41

AlGhamdi, R., Nguyen, A., Nguyen, J., \& Drew, S. (2012). Factors Influencing e-commerce Adoption by Retailers in Saudi Arabia: A quantitative analysis. International Journal of Electronic Commerce Studies.

Al-Mabrouk, K., \& Soar, J. (2006, 19-21 Nov). Identification of Major Issues for Successful IT Transfer in the Arab World: The Preliminary Results. Paper presented at the Innovations in Information Technology, Dubai. http://dx.doi.org/10.1109/innovations.2006.301885

Alshardan, A., Goodwin, R., \& Rampersad, G. (2013). Measuring the benefits of IS in small organizations in developing countries. International Journal of Conceptions on Computing and Information Technology, $1(2), 12-17$.

Anderson, J. C., \& Gerbing, D. W. (1988). Structural equation modeling in practice: A review and recommended two-step approach. Psychological bulletin, 103(3), 411. http://dx.doi.org/10.1037/0033-2909.103.3.411

Apulu, I., \& Latham, A. (2010). Benefits of information and communication technology in small and medium sized enterprises: a case study of a Nigerian SME. UK Academy for Information Systems Conference Proceedings 2010, 7.

Ashrafi, R., \& Murtaza, M. (2008). Use and Impact of ICT on SMEs in Oman. The Electronic Journal of Information Systems Evaluation, 11(3), 125-138.

Azyabi, N., Fisher, J., Tanner, K., \& Gao, S. (2014, 06-09 January ). The Relationship between KM Strategies and IT Applications in SMEs. Paper presented at the 47th Hawaii International Conference on System Sciences (HICSS), Big Island, Hawaii. http://dx.doi.org/10.1109/hicss.2014.453

Bagozzi, R. P., \& Yi, Y. (2011). Specification, evaluation, and interpretation of structural equation models. Journal of the Academy of Marketing Science, 40(1), 8-34. http://dx.doi.org/10.1007/s11747-011-0278-x

Bannigan, K., \& Watson, R. (2009). Reliability and validity in a nutshell. Journal of clinical nursing, 18(23), 3237-3243. http://dx.doi.org/10.1111/j.1365-2702.2009.02939.x

Barendse, M., Oort, F., \& Timmerman, M. (2015). Using exploratory factor analysis to determine the dimensionality of discrete responses. Structural Equation Modeling: A Multidisciplinary Journal, 22(1), 87-101. http://dx.doi.org/10.1080/10705511.2014.934850

Berisha-Namani, M. (2009, 24-27 March). The role of information technology in small and medium sized enterprises in Kosova. Paper presented at the Fulbright Academy 2009 Conference Small Places Can Change the World. , Skopje, Macedonia.

Blili, S., \& Raymond, L. (1993). Information technology: Threats and opportunities for small and medium-sized enterprises. International Journal of Information Management, 13(6), 439-448. http://dx.doi.org/10.1016/0268-4012(93)90060-H 
Cooper, D. R., \& Schindler, P. S. (2006). Business research methods (Eleventh ed.): The McGraw-Hill/Irwin series (Operations and decision sciences).

Cragg, P. B., \& Zinatelli, N. (1995). The evolution of information systems in small firms. Information \& Management, 29(1), 1-8. http://dx.doi.org/10.1016/0378-7206(95)00012-L

Cronbach, L. J. (1951). Coefficient alpha and the internal structure of tests. psychometrika, 16(3), 297-334. http://dx.doi.org/10.1007/bf02310555

Davis, F. D. (1989). Perceived Usefulness, Perceived Ease of Use, and User Acceptance of Information Technology. MIS Quarterly, 13(3), 319-340. http://dx.doi.org/10.2307/249008

DeLone, W. H. (1981). Firm Size and the Characteristics of Computer Use. MIS Quarterly, 5(4), 65-77. http://dx.doi.org/10.2307/249328

DeLone, W. H., \& McLean, E. R. (1992). Information Systems Success: The Quest for the Dependent Variable. Information Systems Research, 3(1), 60-95. http://dx.doi.org/10.1287/isre.3.1.60

DeLone, W. H., \& McLean, E. R. (2003). The DeLone and McLean model of information systems success: a ten-year update. Journal of Management Information Systems, 19(4), 9-30.

DelVecchio, M. (1994). Retooling the staff along with the system. Bests Review, 94(11), 82-83.

Deros, B. M., Yusof, S. M., \& Salleh, A. M. (2006). A benchmarking implementation framework for automotive manufacturing SMEs. Benchmarking, 13(4), 396-430. http://dx.doi.org/10.1108/14635770610676272

Doll, W. J., Xia, W., \& Torkzadeh, G. (1994). A confirmatory factor analysis of the end-user computing satisfaction instrument. MIS Quarterly, 453-461. http://dx.doi.org/10.2307/249524

Fathian, M., Akhavan, P., \& Hoorali, M. (2008). E-readiness assessment of non-profit ICT SMEs in a developing

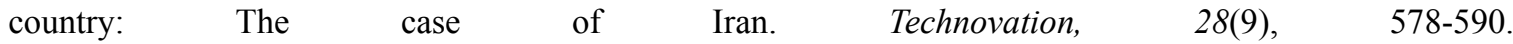
http://dx.doi.org/10.1016/j.technovation.2008.02.002

Fink, D. (1998). Guidelines for the Successful Adoption of Information Technology in Small and Medium Enterprises. International Journal of Information Management, 18(4), 243-253. http://dx.doi.org/10.1016/S0268-4012(98)00013-9

Fornell, C., \& Larcker, D. F. (1981). Structural equation models with unobservable variables and measurement error: Algebra and statistics. Journal of marketing research, 382-388. http://dx.doi.org/10.2307/3150980

Fraenkel, J. R., \& Wallen, N. E. (2009). How to design and evaluate research in education (7th ed.). New York, NY: McGraw-Hill.

Freel, M. S. (2000). Barriers to product innovation in small manufacturing firms. International Small Business Journal, 18(2), 60-80. http://dx.doi.org/10.1177/0266242600182003

Gable, G. G., Sedera, D., \& Chan, T. Z. (2008). Re-conceptualizing information system success: The IS-Impact measurement model. Journal of the Association for Information Systems, 9(7), 377-408.

Gefen, D., Straub, D., \& Boudreau, M. C. (2000). Structural equation modeling and regression: Guidelines for research practice. Communications of the Association for Information Systems, 4(1), 7.

Ghobakhloo, M., \& Tang, S. H. (2015). Information system success among manufacturing SMEs: case of developing countries. Information Technology for Development, 1-28. http://dx.doi.org/10.1080/02681102.2014.996201

Gibb, A. A. (2000). SME Policy, Academic Research and the Growth of Ignorance, Mythical Concepts, Myths, Assumptions, Rituals and Confusions. International Small Business Journal, 18(3), 13. http://dx.doi.org/10.1177/0266242600183001

Gliem, J. A., \& Gliem, R. R. (2003, 8-10 October). Calculating, interpreting, and reporting Cronbach's alpha reliability coefficient for Likert-type scales. Paper presented at the Midwest Research-to-Practice Conference in Adult, Continuing, and Community Education, The Ohio State University, Columbus, $\mathrm{OH}$.

Gorla, N., Somers, T. M., \& Wong, B. (2010). Organizational impact of system quality, information quality, and service quality. The Journal of Strategic Information Systems, 19(3), 207-228. http://dx.doi.org/10.1016/j.jsis.2010.05.001

Grazzi, M., \& Vergara, S. (2012). ICT in developing countries: Are language barriers relevant? Evidence from Paraguay. Information Economics and Policy, 24(2), 161-171. 
http://dx.doi.org/10.1016/j.infoecopol.2011.11.001

Hair, J. F., Black, W. C., Babin, B. J., Anderson, R. E., \& Tatham, R. L. (2006). Multivariate data analysis (Vol. 6): Pearson Prentice Hall Upper Saddle River, NJ.

Hawari, A. a., \& Heeks, R. (2010). Explaining ERP failure in a developing country: a Jordanian case study. Journal of Enterprise Information Management, 23(2), 135-160. http://dx.doi.org/10.1108/17410391011019741

Hinkin, T. R. (1995). A review of scale development practices in the study of organizations. Journal of management, 21(5), 967-988. http://dx.doi.org/10.1177/014920639502100509

Hurley, A. E., Scandura, T. A., Schriesheim, C. A., Brannick, M. T., Seers, A., Vandenberg, R. J., \& Williams, L. J. (1997). Exploratory and confirmatory factor analysis: Guidelines, issues, and alternatives. Journal of organizational behavior, 18(6), 667-683. http://dx.doi.org/10.1002/(SICI)1099-1379(199711)18:6<667::AID-JOB874>3.0.CO;2-T

Irani, Z. (2008). Information systems evaluation: what does it mean? Construction Innovation, Vol. 8 (No. 2 , 2008), pp. 88-91. http://dx.doi.org/10.1108/14714170810867014

Irefin, I., Abdul-Azeez, I., \& Tijani, A. (2012). An Investigative Study of The Factors Affecting The Adoption of Information and Communication Technology in Small and Medium Scale Enterprises in Nigeria. Australian Journal of Business and Management Research Vol, 2(02), 01-09.

Juell-Skielse, G. (2006). ERP adoption in small and medium sized enterprises. Thesis, Data- och systemvetenskap University, Kista. Retrieved from http://urn.kb.se/resolve?urn=urn:nbn:se:kth:diva-3982

Kale, P., Banwait, S., \& Laroiya, S. (2010). Performance evaluation of ERP implementation in Indian SMEs. $\begin{array}{llll}\text { Journal of Manufacturing Technology } & \text { Management, }\end{array}$ http://dx.doi.org/10.1108/17410381011064030

Kartiwi, M., \& MacGregor, R. (2007). Electronic Commerce Adoption Barriers in Small to Medium-Sized Enterprises (SMEs) in Developed and Developing Countries: A Cross-Country Comparison. Journal of Electronic Commerce in Organizations,, 5(3), 35-51. http://dx.doi.org/10.4018/jeco.2007070103

Kimberlin, C. L., \& Winterstein, A. G. (2008). Validity and reliability of measurement instruments used in research. American Journal of Health-System Pharmacy, 65(23). http://dx.doi.org/10.2146/ajhp070364

Koh, S. C. L., Gunasekaran, A., \& Cooper, J. R. (2009). The demand for training and consultancy investment in SME-specific ERP systems implementation and operation. International Journal of Production Economics, 122(1), 241-254. http://dx.doi.org/10.1016/j.ijpe.2009.05.017

Lance, C. E. (2011). More statistical and methodological myths and urban legends. Organizational Research Methods, 14(2), 279-286. http://dx.doi.org/10.1177/1094428110391814

Lefebvre, E., \& Lefebvre, L. A. (1992). Firm innovativeness and CEO characteristics in small manufacturing firms. Journal of Engineering and Technology Management, 9(3), 243-277. http://dx.doi.org/10.1016/0923-4748(92)90018-Z

Levy, M., \& Powell, P. (1998). SME flexibility and the role of information systems. Small Business Economics, 11(2), 183-196. http://dx.doi.org/10.1023/A:1007912714741

Levy, M., \& Powell, P. (2000). Information systems strategy for small and medium sized enterprises: an organisational perspective. The Journal of Strategic Information Systems, 9(1), 63-84. http://dx.doi.org/10.1016/S0963-8687(00)00028-7

Lin, C. Y.-Y. (1998). Success Factors of Small- and Medium-Sized Enterprises in Taiwan: An Analysis of Cases. Journal of Small Business Management, 36(4), 43-56.

Little, T. D., Cunningham, W. A., Shahar, G., \& Widaman, K. F. (2002). To parcel or not to parcel: Exploring the question, weighing the merits. Structural Equation Modeling, 9(2), 151-173. http://dx.doi.org/10.1207/S15328007SEM0902_1

Loh, T. C., \& Koh, S. C. L. (2004). Critical elements for a successful enterprise resource planning implementation in small-and medium-sized enterprises. International Journal of Production Research, 42(17), 3433-3455. http://dx.doi.org/10.1080/00207540410001671679

Mabert, V. A., Soni, A., \& Venkataramanan, M. A. (2003a). Enterprise resource planning: Managing the implementation process. European Journal of Operational Research, 146(2), 302-314. 
http://dx.doi.org/10.1016/S0377-2217(02)00551-9

Mabert, V. A., Soni, A., \& Venkataramanan, M. A. (2003b). The impact of organization size on enterprise resource planning (ERP) implementations in the US manufacturing sector. Omega, 31(3), 235-246. http://dx.doi.org/10.1016/S0305-0483(03)00022-7

MacKenzie, K. D., \& House, R. (1978). Paradigm Development in the Social Sciences: A Proposed Research Strategy. Academy of Management Review, 7-23. http://dx.doi.org/10.5465/AMR.1978.4296297

Manochehri, N., Al-Esmail, R., \& Ashrafi, R. (2012). Examining the Impact of Information and Communication Technologies (ICT) on Enterprise Practices: A Preliminary Perspective from Qatar. The Electronic Journal of Information Systems in Developing Countries, 51.

Martin-Tapia, I., Aragon-Correa, J. A., \& Senise-Barrio, M. E. (2008). Being green and export intensity of SMEs: The moderating influence of perceived uncertainty. Ecological Economics, 68(1-2), 56-67. http://dx.doi.org/10.1016/j.ecolecon.2008.01.032

McCartan-Quinn, D., \& Carson, D. (2003). Issues which Impact upon Marketing in the Small Firm. Small Business Economics, 21(2), 201-213. http://dx.doi.org/10.1023/A:1025070107609

McGrath, J. E. (1964). Toward a "theory of method" for research on organizations. New perspectives in organization research, 533, 533-547.

Mirani, R., \& Lederer, A. L. (1998). An Instrument for Assessing the Organizational Benefits of IS Projects. Decision Sciences, 29(4), 803-838. http://dx.doi.org/10.1111/j.1540-5915.1998.tb00878.x

Modimogale, L., \& Kroeze, J. H. (2011). The Role of ICT within Small and Medium Enterprises in Gauteng. Communications 2011. http://dx.doi.org/10.5171/2011.369288

Myers, B. L., Kappelman, L. A., \& Prybutok, V. R. (1998). A comprehensive model for assessing the quality and productivity of the information systems function: toward a theory for information systems assessment. Information systems success measurement (pp. 94-121). North Texas University, Information Systems Research: IGI Publishing.

Ndiege, J. R. A., Wayi, N., \& Herselman, M. E. (2012). Quality Assessment of Information Systems in SMEs: A Study of Eldoret Town in Kenya. The Electronic Journal of Information Systems in Developing Countries, 51 .

O'Reagan, N., \& Ghobadian., A. (2004). Testing the homogeneity of SMEs: The impact of size on managerial

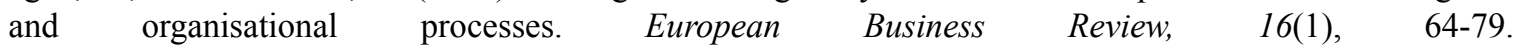
http://dx.doi.org/10.1108/09555340410512411

Pallant, J. (2013). SPSS survival manual: McGraw-Hill International.

Patel, F., Sooknanan, P., Rampersad, G., \& Mundkur, A. (2012). Information Technology, Development, and Social Change (Vol. 32). New York: Routledge.

Petter, S., DeLone, W., \& McLean, E. (2008). Measuring information systems success: models, dimensions, measures, and interrelationships. European Journal of Information Systems, 17(3), 236-263. http://dx.doi.org/10.1057/ejis.2008.15

Rabaa'i, A. A. (2012). Evaluating the success of large-scale, integrated information systems through the lens of IS-impact and IS-support. ( $\mathrm{PhD}$ thesis), Queensland University of Technology.

Rampersad, G. (2008). Management of Innovation Networks in Technology Transfer. (PhD thesis), Business School, The University of Adelaide,.

Rampersad, G., \& Troshani, I. (2013). High-speed broadband: assessing its social impact. Industrial Management \& Data Systems, 113(4), 541-557. http://dx.doi.org/10.1108/02635571311322784

Rampersad, G., Quester, P., \& Troshani, I. (2009). Developing and evaluating scales to assess innovation networks. International Journal of Technology Intelligence and Planning, 5(4), 402-420. http://dx.doi.org/10.1504/IJTIP.2009.029378

Rampersad, G., Quester, P., \& Troshani, I. (2010). Managing innovation networks: Exploratory evidence from ICT, biotechnology and nanotechnology networks. Industrial Marketing Management, 39(5), 793-805. http://dx.doi.org/10.1016/j.indmarman.2009.07.002

Rampersad, G., Troshani, I., \& Plewa, C. (2012). IOS adoption in innovation networks: a case study. Industrial Management \& Data Systems, 112(9), 1366-1382. http://dx.doi.org/10.1108/02635571211278974 
Roztocki, N., \& Weistroffer, H. R. (2011). Information technology success factors and models in developing and emerging economies. Information Technology for Development, 17(3), 163-167. http://dx.doi.org/10.1080/02681102.2011.568220

Said, H., Badru, B. B., \& Shahid, M. (2011). Confirmatory Factor Analysis (Cfa) for Testing Validity And Reliability Instrument in the Study of Education. Australian Journal of Basic \& Applied Sciences, 5(12).

Salmeron, J. L., \& Bueno, S. (2006). An information technologies and information systems industry-based classification in small and medium-sized enterprises: An institutional view. European Journal of Operational Research, 173(3), 1012-1025. http://dx.doi.org/10.1016/j.ejor.2005.07.002

Schreiber, J. B., Nora, A., Stage, F. K., Barlow, E. A., \& King, J. (2006). Reporting structural equation modeling and confirmatory factor analysis results: A review. The Journal of Educational Research, 99(6), 323-338. http://dx.doi.org/10.3200/JOER.99.6.323-338

Schumacker, R. E., \& Lomax, R. G. (2004). A beginner's guide to structural equation modeling: Psychology Press. http://dx.doi.org/10.4324/9781410610904

Seddon, P. B. (1997). A Respecification and Extension of the DeLone and McLean Model of IS Success. Information Systems Research, 8(3), 240-253. http://dx.doi.org/10.1287/isre.8.3.240

Seddon, P., \& Kiew, M. Y. (1996). A Partial Test and Development of Delone and Mclean's Model of IS Success. Australasian Journal of Information Systems, 4(1). http://dx.doi.org/10.3127/ajis.v4i1.379

Seibert, M. J., III. (2004). The identification of strategic management counseling competencies essential for the Small Business and Technology Development Center: A modified Delphi study. (Doctor of Philosophy Thesis ), North Carolina State University, United States - North Carolina.

Shang, S., \& Seddon, P. B. (2002). Assessing And Managing The Benefits Of Enterprise Systems: The Business Manager's Perspective. Information Systems Journal, 12(4), 271-299. http://dx.doi.org/10.1046/j.1365-2575.2002.00132.x

Skoko, H. (2012). Influencing Factors Model of Information and Communication Technology (ICT) in Saudi Arabian Small and Medium Enterprises (SMEs). The GCC Economies, 229-234. http://dx.doi.org/10.1007/978-1-4614-1611-1_19

Skoko, H., \& Ceric, A. (2010, 29 June- 2 July). Study on Information and Communication Technology (ICT) Models of Adoption and Use in the Kingdom of Saudi Arabian SMEs. Paper presented at the The 6th International Conference on Social and Organizational Informatics and Cybernetics: SOIC 2010 in the context of The 4th International Multi-Conference on Society, Cybernetics and Informatics: IMSCI 2010, Orlando, FL USA.

Snider, B., da Silveira, G. J. C., \& Balakrishnan, J. (2009). ERP implementation at SMEs: analysis of five Canadian cases. International Journal of Operations \& Production Management, 29(1/2), 4-29. http://dx.doi.org/10.1108/01443570910925343

Soja, P. (2008). Difficulties in enterprise system implementation in emerging economies: Insights from an exploratory study in Poland. Information Technology for Development, 14(1), 31-51. http://dx.doi.org/10.1002/itdj.20086

Straub, D., Boudreau, M. C., \& Gefen, D. (2004). Validation guidelines for IS positivist research. The Communications of the Association for Information Systems, 13(1), 63. http://dx.doi.org/10.4018/978-1-59140-144-5.ch002

Sun, A. Y. T., Yazdani, A., \& Overend, J. D. (2005). Achievement assessment for enterprise resource planning (ERP) system implementations based on critical success factors (CSFs). International Journal of Production Economics, 98(2), 189-203. http://dx.doi.org/10.1016/j.ijpe.2004.05.013

Tate, M., Sedera, D., McLean, E., \& Burton-Jones, A. (2014). Information Systems Success Research: The "20-Year Update?" Panel Report from PACIS, 2011. Communications of the Association for Information Systems, 34(1), 63.

Urbach, N., Smolnik, S., \& Riempp, G. (2009). The state of research on information systems success. Business \& Information Systems Engineering, 1(4), 315-325. http://dx.doi.org/10.1007/s12599-009-0059-y

Vrgovic, P., Glassman, B., Walton, A., \& Vidicki, P. (2012). Open innovation for SMEs in developing countries-an intermediated communication network model for collaboration beyond obstacles (revision). INNOVATION: Management, Policy \& Practice(0), 587-614. http://dx.doi.org/10.5172/impp.2012.587 
Waverman, L., Coyle, D., \& Souter, D. (2011). ICT in Saudi Arabia: A Socio-Economic Impact Review. Kingdom of Saudi Arabia: Produced by STC in collaboration with VHM-Beirut, Regulatory Affairs.

Wei, K. S., Loong, A. C., Leong, Y. M., \& Ooi, K. B. (2009, 7-8 December). Measuring ERP system success: a respecification of the Delone and McLean's IS success model. Paper presented at the Symposium on Progress in Information and Communication Technology (SPICT'09), Kuala Lumpur, Malaysia

Yang, C., Nay, S., \& Hoyle, R. H. (2009). Three approaches to using lengthy ordinal scales in structural equation models: Parceling, latent scoring, and shortening scales. Applied Psychological Measurement. http://dx.doi.org/10.1177/0146621609338592

Yap, C., Soh, C., \& Raman, K. (1992). Information systems success factors in small business. Omega, 20(5-6), 597-609. http://dx.doi.org/10.1016/0305-0483(92)90005-R

\section{Copyrights}

Copyright for this article is retained by the author(s), with first publication rights granted to the journal.

This is an open-access article distributed under the terms and conditions of the Creative Commons Attribution license (http://creativecommons.org/licenses/by/3.0/). 